\title{
Vitamin D Megadose: Definition, Efficacy in Bone Metabolism, Risk of Falls and Fractures
}

This article was published in the following Dove Press journal:

Open Access Rheumatology: Research and Reviews

\author{
Jemina Narvaez (iD) \\ Genessis Maldonado (D) \\ Roberto Guerrero (1D' \\ Osvaldo Daniel Messina ${ }^{2}$ \\ Carlos Rios' \\ 'Rheumatology Department, Espíritu \\ Santo University, Guayaquil, Ecuador; \\ ${ }^{2}$ Rheumatology Department, Hospital \\ Cosme Argerich, Buenos Aires, \\ Argentina
}

\begin{abstract}
Introduction: Currently, approximately more than one billion people around the world are considered to have deficient levels of vitamin D. International consensus recommends vitamin D supplementation to high-risk patients (advanced age, osteoporosis, liver failure, malabsorption syndromes, etc.) and those with levels below $30 \mathrm{ng} / \mathrm{mL}$. There are several vitamin D formulations and dosages available, including megadoses. At the moment, there is no consensus on the definition of megadoses. The purpose of this review is to define what is a megadose and analyze its effectiveness in bone metabolism, risk of fractures and falls.

Conclusion: The administration of doses higher than 100,000 IU of vitamin D is considered a megadose. It is evident that the use of megadoses increases serum concentrations of vitamin D; however, there has been no evidence of a decrease in the risk of falls, vertebral fractures or changes in bone mineral density.
\end{abstract}

Keywords: vitamin D, supplementation, falls, bone mineral density

\section{Introduction}

Vitamin D is a pleiotropic steroid hormone, mostly formed from the conversion of 7-dihydrocholesterol to pre-vitamin D3 by ultraviolet light in the keratinocytes. Vitamin D3 is then converted into 25-hydroxycholecalciferol (25-OHD3) in the liver by the enzyme 25-hydroxylase and finally in the proximal tubule of the kidney, the enzyme 25-hydroxyvitamin D-1-hydroxylase converts it into its active form, 1.25dihydrocolecalciferol. ${ }^{1}$

In recent years, there has been an increase in the number of publications about vitamin $\mathrm{D}$ and bone metabolism. ${ }^{2-5}$ Vitamin $\mathrm{D}$ allows for calcium absorption at the intestinal level (Figure 1), making calcium homeostasis the main function of vitamin D.

Nowadays it is considered that approximately more than one billion people around the world are vitamin D insufficient or deficient and that $50-100 \%$ of older men and women in the United States and Europe are vitamin D deficient. ${ }^{6}$ In Latin American countries, which have a high sun exposure index, vitamin D levels are lower. Doses between 800 and $2000 \mathrm{IU}$ and serum levels $\geq 30 \mathrm{ng} / \mathrm{mL}$ of vitamin $\mathrm{D}$ have been shown to decrease the risk of fracture. ${ }^{7}$ Wahl et al Mapped the overall vitamin D status based on a systematic review in different countries. It was evident that only $14 \%$ of the countries studied had vitamin D levels above 30ng/mL, 37\% had levels between 29 and $20 \mathrm{ng} / \mathrm{mL}$ and $49 \%$ had levels between 19 and $10 \mathrm{ng} / \mathrm{mL}^{8}{ }^{8}$

International consensus recommends vitamin D supplementation to high-risk patients (advanced age, osteoporosis, liver failure, malabsorption syndromes, etc.) and those with levels below $30 \mathrm{ng} / \mathrm{mL} .^{9,10}$ There are several vitamin D formulations
Correspondence: Genessis Maldonado Email genesismaldonadovelez92@gmail. com 


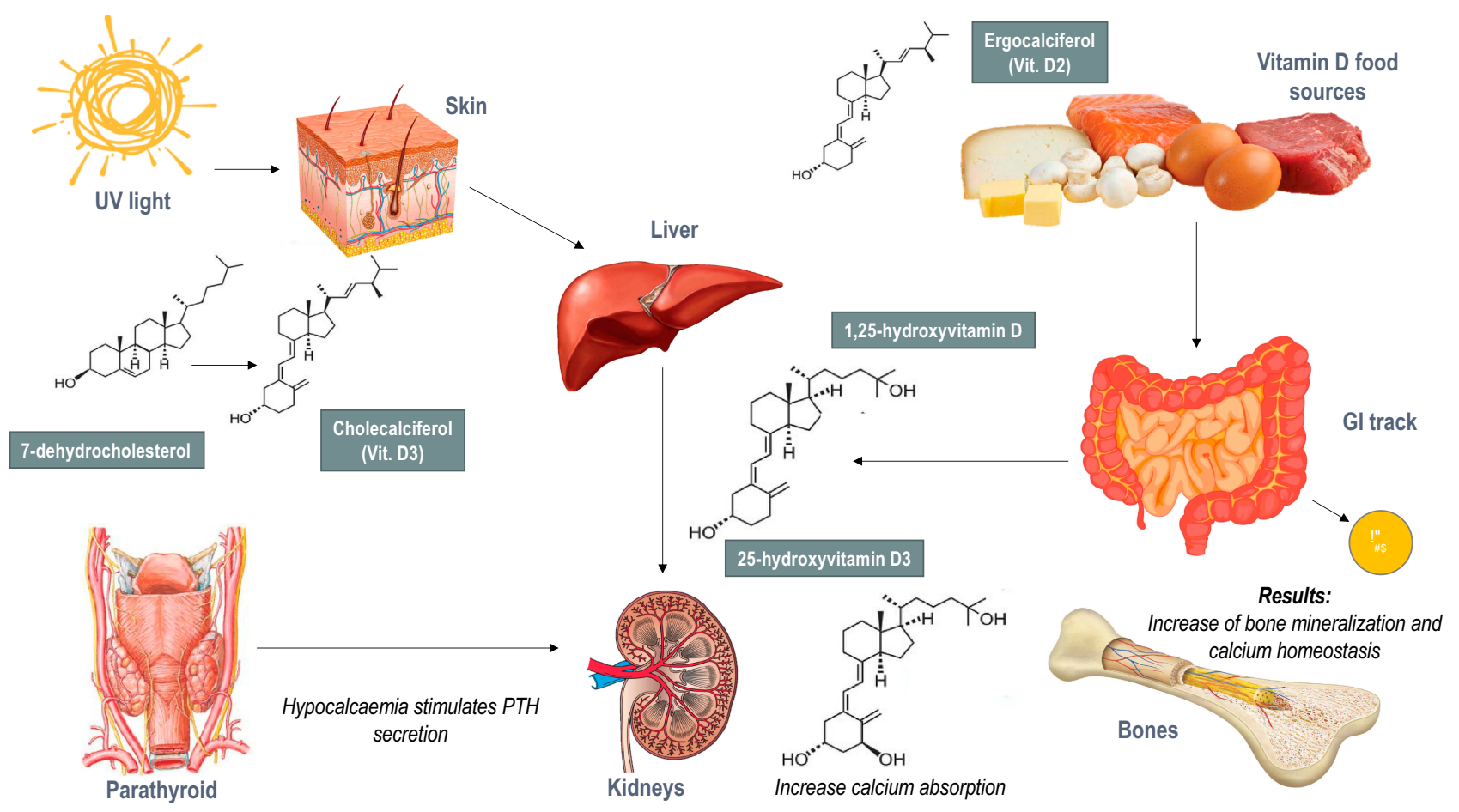

Figure I The role of vitamin D in bone metabolism.

and dosages available, including megadoses. At the moment, there is no consensus on the definition of megadoses, however, several studies have used doses higher than 100,000 IU weekly/monthly and have classified them as megadoses. ${ }^{11-15}$ The purpose of this review is to define what is a megadose, and analyze its effectiveness in bone metabolism, risk of fractures and falls.

\section{Search Methodology Search Strategy}

A systematic search for documents was carried out in the following databases: PubMed, EMBASE, and Cochrane Library. Keywords included "vitamin D", "megadoses", "high-dose", "bone mineral density", "risk of fracture", "muscle strength" and "falls". The search strategy included free text and MeSH terms. Additional studies were sought from the reference list of certain primary studies and relevant reviews.

\section{Study Selection}

A total of 1178 articles were found, of which 40 were selected by peer-review evaluation. Article selection was limited to studies and systematic reviews in humans and adults, in the English and Spanish languages. Articles that reported associations between high doses of vitamin D and falls, risk of fracture, muscle strength, and bone mineral density were selected. Studies with vitamin D formulations other than ergocalciferol were excluded.

The study was approved by the Ethics and Teaching Committee of the Centro de Reumatología y Rehabilitación (CERER) with a registration number: No.002/2020; Folio 01: Book of Acts No.1.

\section{Vitamin D Supplementation}

Data from studies in several countries show that serum concentrations of $25(\mathrm{OH}) \mathrm{D}$ should be between $25-50 \mathrm{ng} / \mathrm{mL},{ }^{16-20}$ which corresponds to a daily vitamin D intake of $800 \mathrm{IU}^{10}$ Guidelines recommend that patients with osteoporosis should be supplemented with $800 \mathrm{IU}(20 \mu \mathrm{g})$ of vitamin D per day, ${ }^{21,22}$ higher levels such as $2000 \mathrm{IU}(50 \mu \mathrm{mg})$ daily can also be administered in specific cases, but do not represent a majority in osteoporosis treatment guidelines. Vitamin D requirements vary according to the different guidelines. Table 1 describes the recommendations for vitamin $\mathrm{D}$ treatment according to the age group, these range from 400 to $2000 \mathrm{IU}$.

The Endocrinology Society guidelines recommend 6000 IU $(150 \mu \mathrm{g})$ daily for 8 weeks and a maintenance dose of 1500-2000 IU $(37.5-50 \mu \mathrm{g})$ daily to patients with vitamin D deficiency $(\leq 20 \mathrm{ng} / \mathrm{mL})$ and with following conditions: ${ }^{9}$ Rickets, osteomalacia, osteoporosis, chronic kidney disease, 
Table I Vitamin D Therapy Recommendations According to Age Group

\begin{tabular}{|c|c|c|c|}
\hline Institution & $\begin{array}{l}\text { Age } \\
\text { (Years) }\end{array}$ & Dosage & $\begin{array}{l}\text { Therapeutic } \\
\text { Objective }\end{array}$ \\
\hline \multirow{2}{*}{$\begin{array}{l}\text { National Academy of } \\
\text { Medicine, 20II (USA } \\
\text { and Canada) } \\
55\end{array}$} & $<1$ & $400 \mathrm{IU}$ & \multirow[t]{2}{*}{$20 \mathrm{ng} / \mathrm{mL}$} \\
\hline & $\mathrm{I}-70$ & $600 \mathrm{IU}$ & \\
\hline \multirow{2}{*}{$\begin{array}{l}\text { Society of } \\
\text { endocrinology, 20119 }\end{array}$} & $<1$ & 400-1000 IU & \multirow[t]{2}{*}{$30 \mathrm{ng} / \mathrm{mL}$} \\
\hline & $\begin{array}{l}1-18 \\
>18\end{array}$ & $\begin{array}{l}600-1000 \mathrm{IU} \\
1500-2000 \mathrm{IU}\end{array}$ & \\
\hline \multirow{2}{*}{$\begin{array}{l}\text { DACH countries, } \\
2012 \text { (Austria, } \\
\text { Germany and } \\
\text { Switzerland) }{ }^{64}\end{array}$} & $<1$ & $400 \mathrm{IU}$ & \multirow[t]{2}{*}{$20 \mathrm{ng} / \mathrm{mL}$} \\
\hline & $>1$ & $800 \mathrm{IU}$ & \\
\hline \multirow{2}{*}{$\begin{array}{l}\text { Opinion leaders of } \\
\text { vitamin D, } 2013 \\
\text { (EVIDAS, Central } \\
\text { Europe) }{ }^{65}\end{array}$} & $\begin{array}{l}0-6 \\
\text { months }\end{array}$ & $400 \mathrm{IU}$ & \multirow[t]{2}{*}{$30 \mathrm{ng} / \mathrm{mL}$} \\
\hline & $\begin{array}{l}6-12 \\
\text { months } \\
1-18 \\
\text { months } \\
16-45\end{array}$ & $\begin{array}{l}400-600 \text { IU } \\
600-1000 \text { IU } \\
\text { I500-2000 IU }\end{array}$ & \\
\hline \multirow[t]{5}{*}{$\begin{array}{l}\text { GULF, } 2018 \text { (Arab } \\
\text { Emirates) }\end{array}$} & $\begin{array}{l}0-6 \\
\text { months }\end{array}$ & $400 \mathrm{IU}$ & \multirow[t]{5}{*}{$30 \mathrm{ng} / \mathrm{mL}$} \\
\hline & $\begin{array}{l}6-12 \\
\text { months }\end{array}$ & 400-600 IU & \\
\hline & $\begin{array}{l}\mathrm{I}-18 \\
\text { months }\end{array}$ & $600-1000 \mathrm{IU}$ & \\
\hline & $19-65$ & 800-2000 IU & \\
\hline & $>65$ & $1000-2000 \mathrm{IU}$ & \\
\hline
\end{tabular}

liver failure, malabsorption syndromes (cystic fibrosis, inflammatory bowel disease, Crohn's disease, bariatric surgery, radiation enteritis), hyperparathyroidism, medications (antiepileptic, antiretroviral, antifungal, cholestyramine), African American and Hispanic population, pregnant women, older adults and granuloma-forming diseases (sarcoidosis, tuberculosis, histoplasmosis).

Doses of 400-800 IU daily increase serum levels of vitamin $\mathrm{D}$, reduces PTH levels and as a result decreases bone resorption marker levels. ${ }^{23-25}$ The first studies of combined oral vitamin D and calcium therapy were conducted by Chapuy et al, who studied the relationship between supplementation and the frequency of hip fracture and other non-vertebral fractures. 800 IU of cholecalciferol was administered with $1.2 \mathrm{~g}$ of calcium daily in healthy women with an average age of 84 years for a period of 18 months. They showed that in the group that received vitamin $\mathrm{D}$ plus calcium, the hip fracture number decreased by $43 \%(p=0.043)$ and a decrease in the total number of non-vertebral fractures by $32 \%(\mathrm{p}=$ $0.015)$ compared to the placebo group. ${ }^{26}$ DawsonHughes et al evaluated the effect of cholecalciferol (700 IU plus $500 \mathrm{mg}$ of calcium) on bone metabolism and the incidence of non-vertebral fractures in 389 subjects older than 65 years. This study reported higher fracture rates in the placebo group than in other controlled trials, where about $22 \%$ had fractures compared to $12 \%$ of other similar studies. ${ }^{27}$

Yong et al evaluated in a metanalysis serum vitamin D concentrations before and after supplementation at different doses, indicating that supplementation of doses higher than 100,000 IU were not effective in improving vitamin D levels. ${ }^{28}$

\section{Definition: What's a Megadose?}

Megadoses have been described as the consumption or administration of nutrients in supraphysiological doses that exceed the recommended dietary ration ten or more times. Its use has been reported since before 1980, spreading this practice in large part by the literature and media that support its use; promising effects that vary from prevention and cure of various diseases to stress relief. ${ }^{29}$ The first recorded supraphysiological dose of vitamin D comes from a study done in Finland in 1992 by Heikinheimo et al who's goal was to investigate its effects on the risk of fractures in older adults. ${ }^{11}$

There is currently no consensus regarding the definition of a megadose, however, several studies use the term "megadoses" to refer to doses higher than 100,000 IU of vitamin D. Cavalcante et al rated megadoses as the use of $200,000 \mathrm{IU}$ of cholecalciferol in a single administration. ${ }^{30}$ Tarcin et al used "megadoses" when administering 300,000 IU of cholecalciferol monthly for 3 months, to patients with vitamin $\mathrm{D}$ deficiency and evaluated their endothelial function. ${ }^{14}$ Table 2 describes the studies that used megadoses for the evaluation of different entities.

Other studies such as VITDISH used megadoses of cholecalciferol (100,000 IU) every 3 months to assess the effects on blood pressure, arterial stiffness, cholesterol levels and endothelial function, without obtaining satisfactory results. ${ }^{33}$ Scragg et al also used megadoses of cholecalciferol (100,0000-200,000 IU monthly) for the prevention of cardiovascular events, without finding significant differences with the placebo group, so they did not recommend its use for the reduction of cardiovascular 
risk. ${ }^{34}$ Trivedi et al used megadoses of cholecalciferol (100,000 IU every 4 months) for the evaluation of the risk of fracture, and demonstrated a decrease in the incidence of fracture by $22 \%$; however, the patients studied were selected from a base of retired doctors from England. ${ }^{35}$ Sanders et al evaluated the frequency of fractures and falls in patients that had been administered with megadoses of cholecalciferol (500,000 IU annually), without finding significant data to support their use for the prevention of falls and fractures. ${ }^{15}$ The most recent study by The National Heart, Lung, and Blood Institute PETAL Clinical Trials Network showed that the use of 540,000 IU of vitamin D3 in critically ill patients with vitamin D deficiency did not improve the 90-day mortality rate compared to placebo group. ${ }^{36}$ Although there is no universal definition of the term megadoses, many studies call the administration of Vitamin D in doses greater than 100,000 IU megadoses.

\section{Vitamin D and Risk of Falls}

Falls are related to a lower quality of life, increased mortality and morbidity. ${ }^{37}$ According to WHO data, of all years lived with disabilities, falls are the third most common cause. ${ }^{38}$ Approximately $30 \%$ of people over 65 have at least one fall per year, $15 \%$ have more than two annual falls and $5 \%$ of all falls result in fractures. ${ }^{39-41}$

Deficient levels of vitamin D have been shown to have a negative effect on muscle strength, as there is a reduction in type II muscle fibers. ${ }^{42}$ Vitamin D receptor promotes the synthesis of rapid type II proteins in the muscle, which are responsible for rapid contraction and balancing activities of short duration and high intensity; resulting in muscle mass being a relevant factor for the prevention of falls. ${ }^{43}$ Snijder et al showed an association between serum levels of $25(\mathrm{OH})$ $\mathrm{D}$ and the risk of falls in older adults. Patients who presented levels $<10 \mathrm{ng} / \mathrm{mL}$ had a risk of falling two to three times higher in 1 year than those who had normal levels of vitamin $\mathrm{D}^{44}$

Smith et al studied the frequency of falls at different doses of ergocalciferol (400, 800, 1600, 2400, 3200, 4000 and 4800 IU daily) for one year, it was evident that in the groups that received $1600-3200 \mathrm{IU}$ of vitamin D, the frequency of falls was lower compared to the groups that received doses higher than $4000 \mathrm{IU}$; leaving in evidence that high doses and megadoses increase the risk of falling. In addition, the authors showed that, in the subgroup of patients with previous falls, the rate of falls was $68 \%$ in low doses of vitamin D, $27 \%$ in medium doses and $100 \%$ in high doses. ${ }^{45}$
Sanders et al compared a single annual dose of 500,000 IU orally of cholecalciferol versus placebo in 2256 women over 70 years old with a follow-up period of 3 to 5 years. It was reported that women in the cholecalciferol group had 171 fractures versus 135 fractures in the placebo group ( $\mathrm{p}=0.047)$; in addition 837 women in the vitamin D group reported 2893 falls versus 2512 falls of 769 women in the placebo group $(\mathrm{p}=0.03){ }^{15}$

These studies show that although vitamin $D$ megadoses are effective in increasing serum values of $25(\mathrm{OH}) \mathrm{D}$, they are not effective in decreasing the risk of fracture. ${ }^{15,43}$ Sanders et al showed that serum vitamin D levels increase considerably after megadoses of cholecalciferol, however, over time these levels drop suddenly and continue to decrease until they reach levels similar to the placebo group. ${ }^{15}$

It has even been controversial to demonstrate its use for the improvement of muscle strength and functionality of healthy or fragile patients. Latham et al in 2003 proposed to determine the efficacy of a single dose of 300,000 IU of ergocalciferol and 10 weeks of quadriceps resistance exercises to reduce falls and improve physical performance in frail older adults. It was found that vitamin D did not alter physical performance measures, even in patients with insufficient serum levels of 25 (OH) D $(<20 \mathrm{ng} / \mathrm{mL}){ }^{46}$

\section{Megadoses and Risk of Fractures}

Smith et al conducted a study, in which they administered $300,000 \mathrm{IU}$ per year of intramuscular ergocalciferol for 3 years in 9440 women and men over 75 years. In the placebo group, $3.87 \%$ men and $7.70 \%$ women had incidental fractures compared to $3.14 \%$ men and $9.26 \%$ women in the vitamin D group. In addition, the researchers found no evidence of a protective effect of vitamin $\mathrm{D}$ against fractures or falls; concluding that IM administration of vitamin D does not reduce the risk of non-vertebral fractures. ${ }^{13}$

Lyons et al administered 100,000 IU of oral ergocalciferol every 4 months in 3440 subjects, and showed that supplementation to reduce the incidence of fractures was not sufficient, as 205 fractures were recorded in the intervention group and 218 fractures in the control group with a risk ratio of $0.85 .^{47}$

Heikinheimo et al studied the use of megadoses as fracture prophylaxis in elderly patients. They administered 150,000-300,000 IU of ergocalciferol annually over a 4-year period. In the group that received vitamin D, $16.4 \%$ presented fractures and in the control group $21.8 \%(\mathrm{p}=0.034)$. However, when the type of fracture was evaluated, the incidence of lower limb fractures in the 


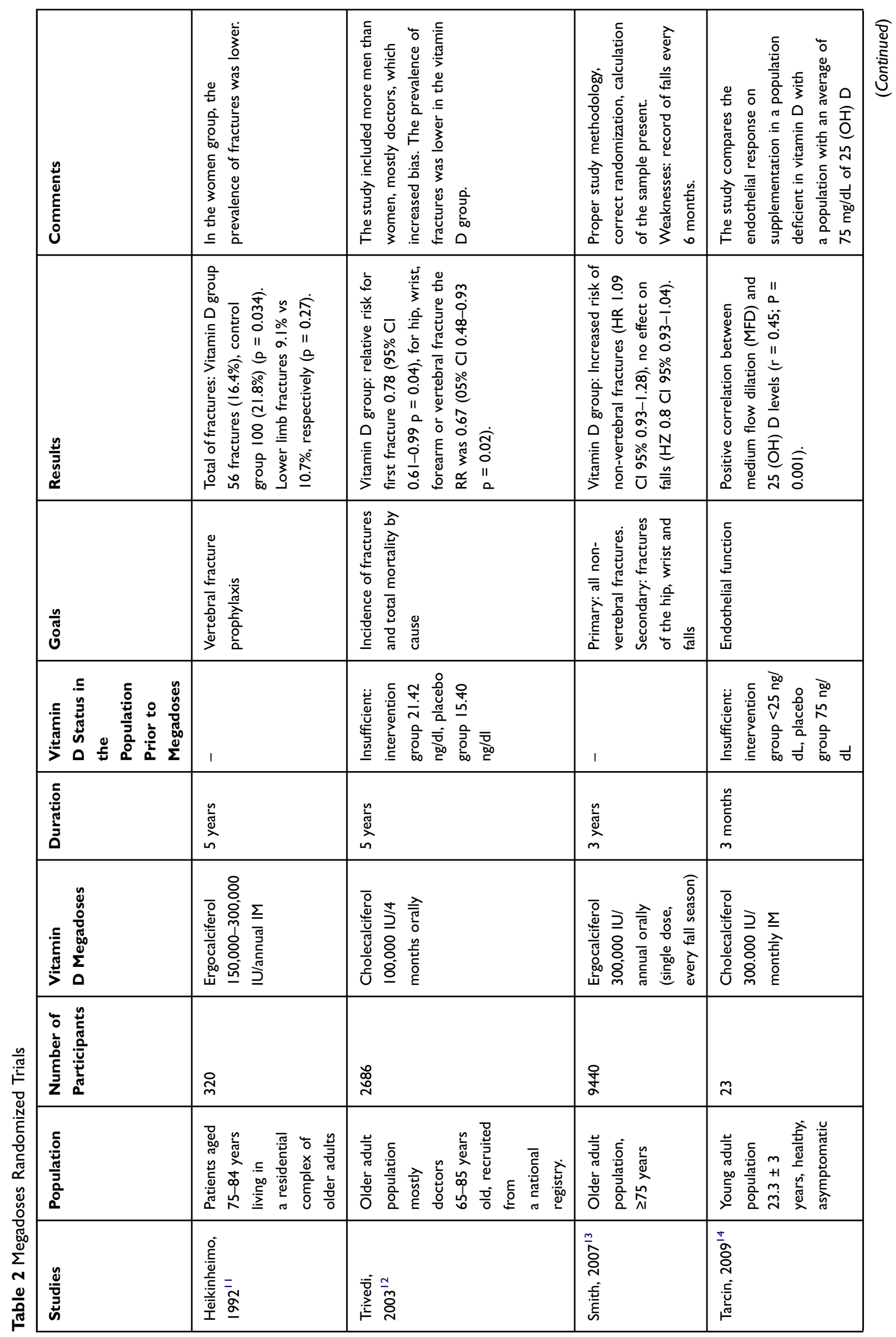




\begin{tabular}{|c|c|c|c|c|}
\hline 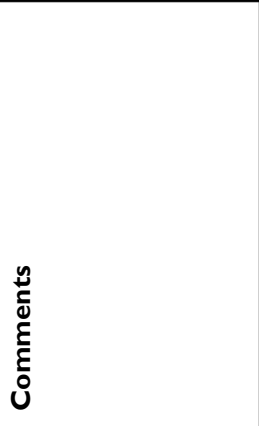 & 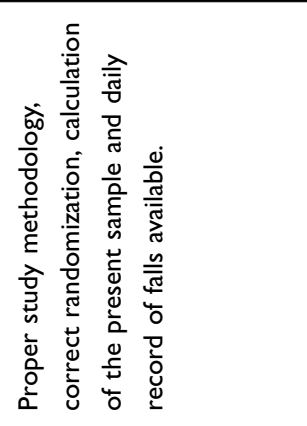 & 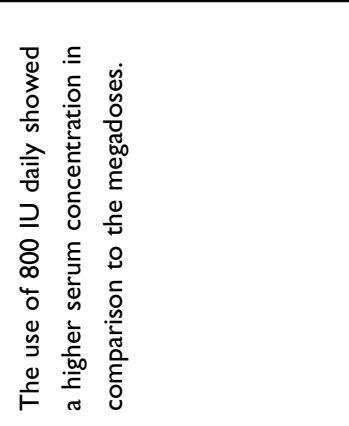 & 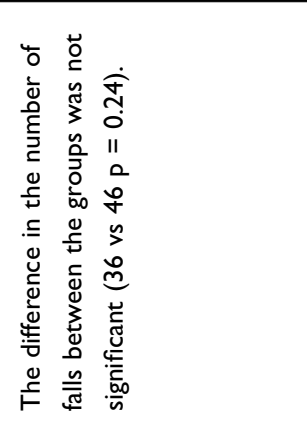 & 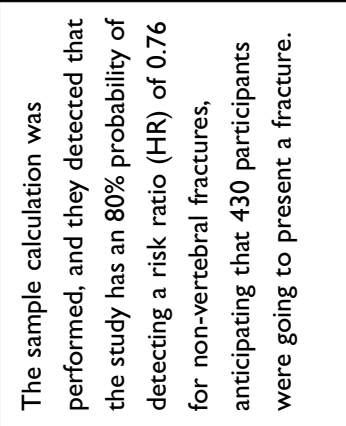 \\
\hline 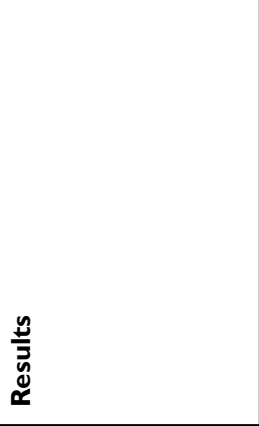 & 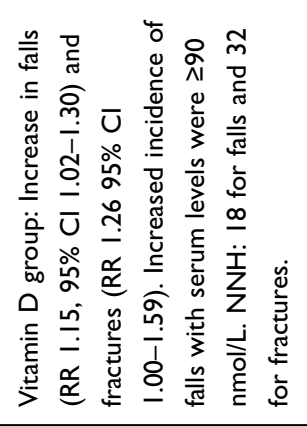 & 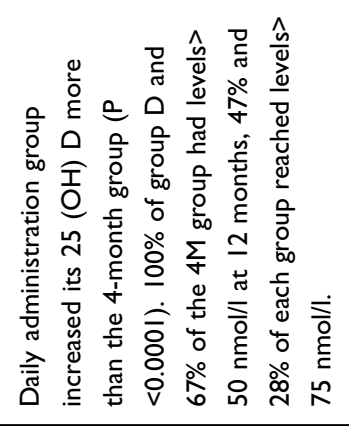 & 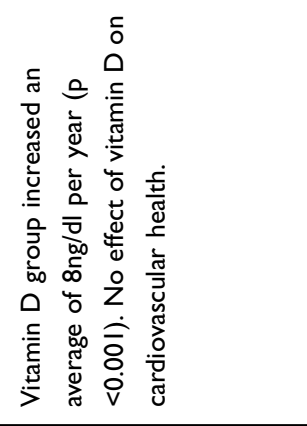 & 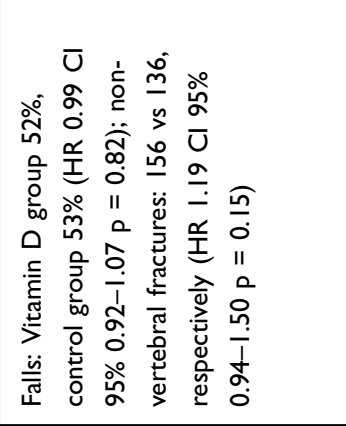 \\
\hline $\begin{array}{l}\frac{n}{\pi} \\
\text { ப் }\end{array}$ & 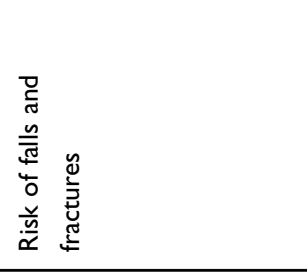 & 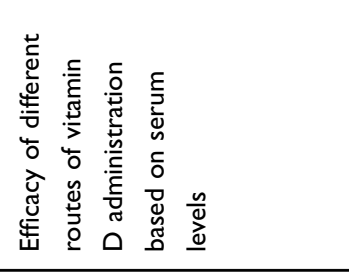 & 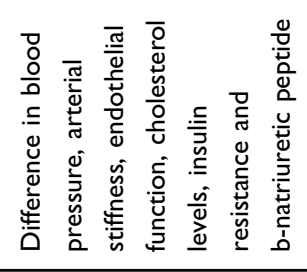 & 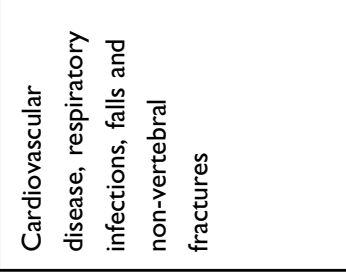 \\
\hline 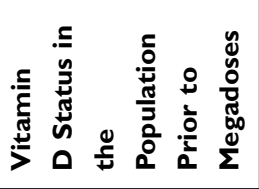 & 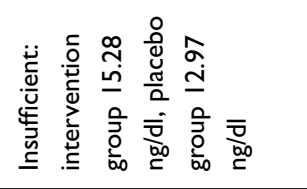 & 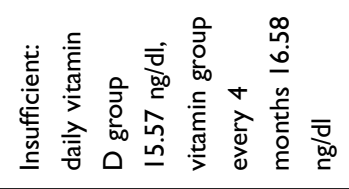 & 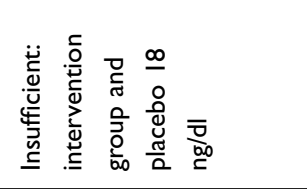 & 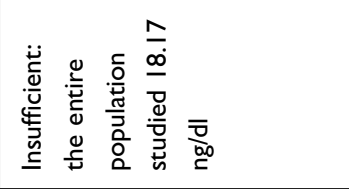 \\
\hline 竞 & 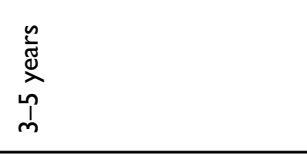 & 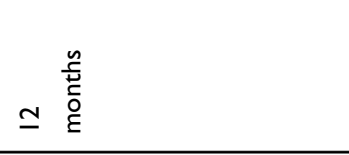 & $\stackrel{\grave{\Phi}}{\stackrel{\grave{\Xi}}{2}}$ & 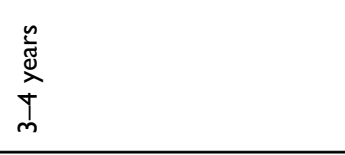 \\
\hline 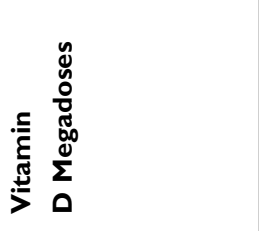 & 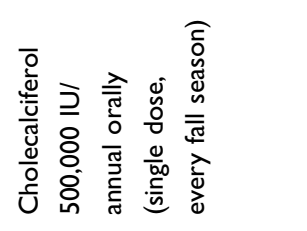 & 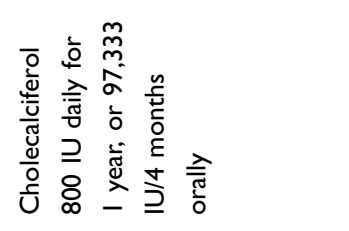 & 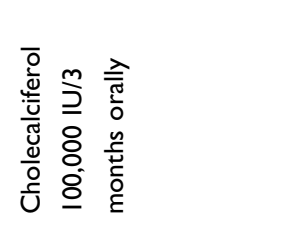 & 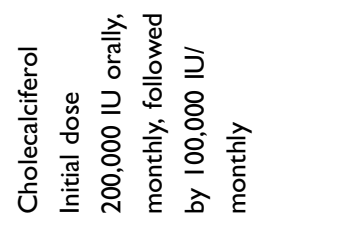 \\
\hline 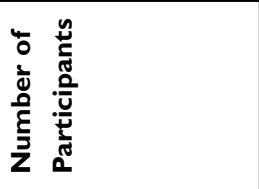 & $\stackrel{\stackrel{N}{N}}{\text { N }}$ & 우 & 옴 & $\frac{O}{\bar{n}}$ \\
\hline 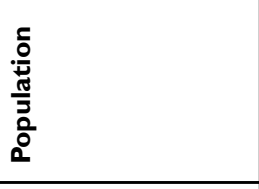 & 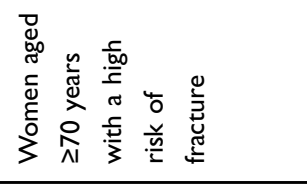 & 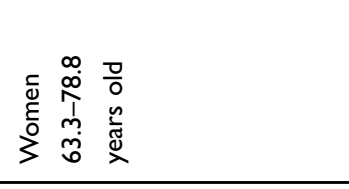 & 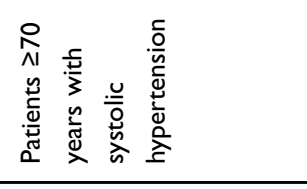 & 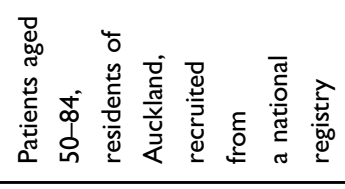 \\
\hline 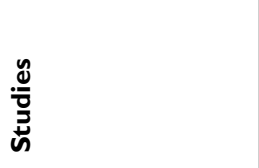 & 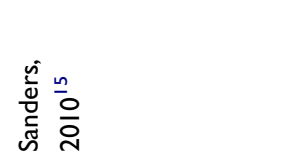 & 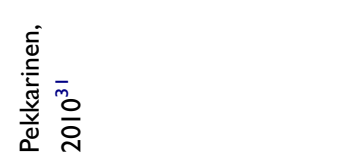 & 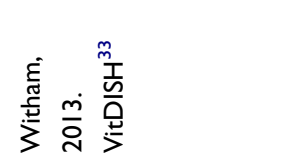 & 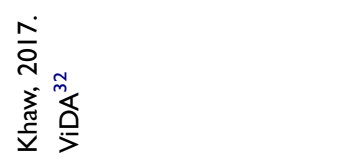 \\
\hline
\end{tabular}




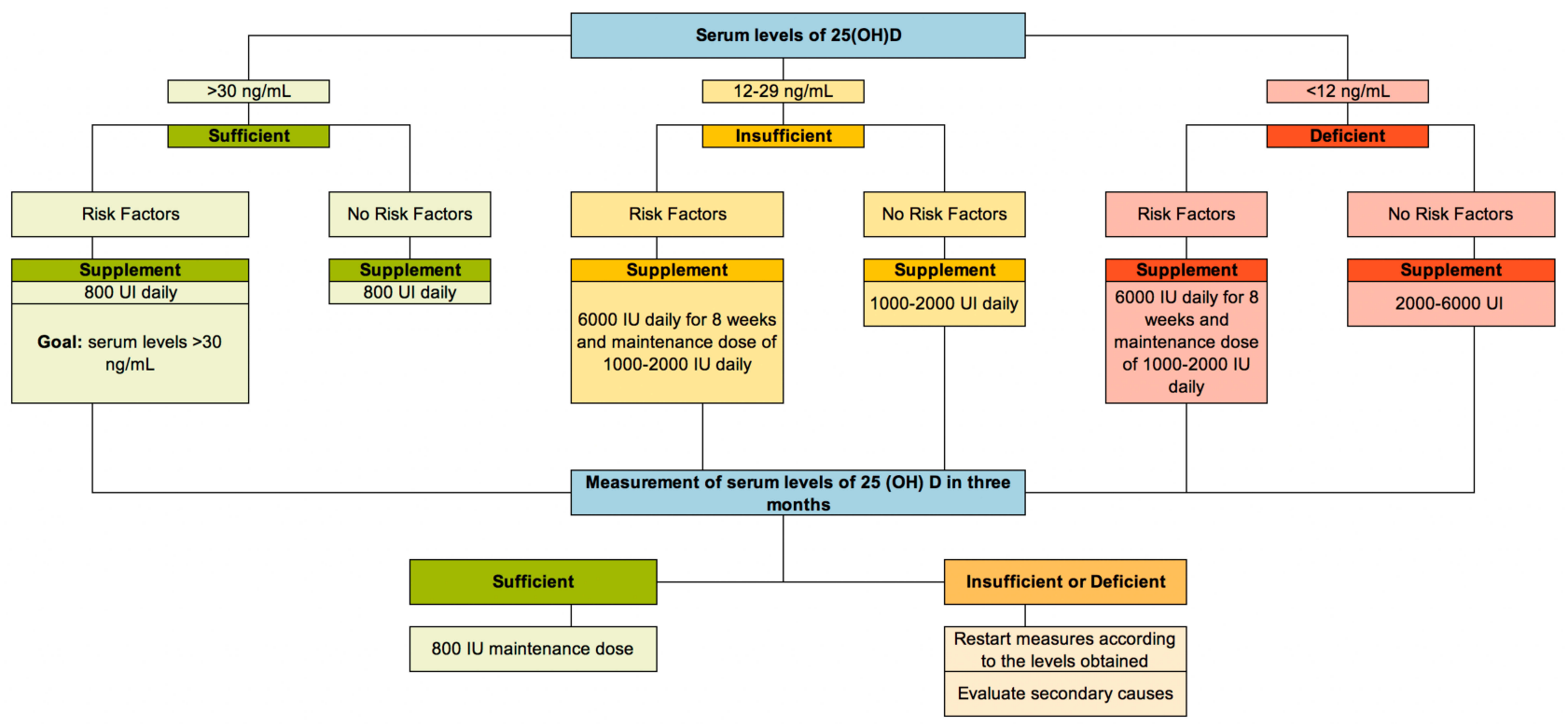

Figure 2 Vitamin D supplementation algorithm.

vitamin D group was $9.1 \%$ versus $10.7 \%$ in the control group $(\mathrm{p}=0.27)$. $^{11}$

In contrast, one of the few studies that has shown benefits with the administration of megadoses has been conducted by Trivedi et al. They administered 100,000 IU of oral cholecalciferol every 4 months to 2686 doctors in Great Britain aged 65 years or older. 268 incidental fractures and 147 osteoporotic fractures were recorded. In the group that received vitamin $\mathrm{D}$, the incidence of the first fracture at any site decreased by $22 \%$ and the incidence of hip, wrist and forearm fractures was reduced by $33 \%$. There was no significant data on the relative risk of mortality and vitamin D $(\mathrm{p}=0.18)^{12}$

Recently, Reid et al conducted a clinical trial to determine the effect of vitamin $\mathrm{D}$ megadoses on bone mineral mass in patients with insufficient levels of $25(\mathrm{OH}) \mathrm{D}$. A monthly dose of 100,000 IU of cholecalciferol was administered for two years and bone mass controls were performed by densitometry, no significant changes in the lumbar spine were evidenced, concluding that megadoses do not have a positive effect on the increase in bone mineral mass. ${ }^{48}$

\section{Other High Doses of Vitamin D}

Clinical trials evaluating the efficacy of Vitamin D have been performed in which daily doses of 10,000 IU are administered $^{49}$ or at weekly and monthly intervals with doses ranging from 20,000 to 60,000 IU. ${ }^{43,50-53}$ In 2008, IshShalom et al analyzed the effects of the different dosages of cholecalciferol in three intervention groups: 1500 IU daily,
10,500 IU weekly and 45,000 IU every 28 days, for two months. Although a greater increase in serum vitamin D concentration was observed on the first day after administration of the monthly dose, no significant differences were observed in serum concentrations of $25(\mathrm{OH}) \mathrm{D}$ of the three groups after two months of intervention; concluding that vitamin D supplementation is equally effective with the three administration frequencies evaluated. ${ }^{52}$

In contrast, Singh et al studied two intervention groups in patients with vitamin D deficiency and musculoskeletal symptoms such as myalgia, fatigue, malaise and paresthesia; The first group was administered 60,000 IU weekly of cholecalciferol and the second, 1000 IU daily. The effect of the interventions in reducing symptoms and the increase in serum levels of vitamin D was compared. After 10 weeks of followup, the two groups reported symptomatic improvement. However, a greater increase in serum concentrations of 25 $(\mathrm{OH}) \mathrm{D}$ was observed in the high-dose group with an average difference of $28.33 \mathrm{ng} / \mathrm{mL}$ between the groups. ${ }^{53}$

Burt et al evaluated the effect of cholecalciferol supplementation on bone mineral density in patients with adequate levels of vitamin D. They selected three intervention groups for daily administration of vitamin D (400 IU, $4000 \mathrm{IU}$ and 10,000 IU) with a follow-up period of three years. The authors found that patients who received $10,000 \mathrm{IU}$ had greater bone loss compared to those who received 400 IU. $^{49}$

Bischoff-Ferrari et al used monthly high doses of cholecalciferol for the evaluation of functional impairment. They 
supplemented women older than 70 years with vitamin $\mathrm{D}$ deficiency and functional impairment and defined three groups with the following monthly dosages: 24,000 IU low dose control group, group with a 60,000 IU dose, and a group of $24,000 \mathrm{IU}$ plus $300 \mu \mathrm{m}$ of calcifediol. They showed that 60,000 and 24,000 IU plus calcifediol increase serum levels, however, they were not effective in improving the function of the lower extremities, and in turn, the risk of falls was higher. It was observed that, paradoxically, adults who reached the highest quartile of vitamin D (44.7-98.9 ng/mL) at 12 months of follow-up were 5.5 times more likely to fall compared to the group that reached the lower quartile below $21.3-30.3 \mathrm{ng} / \mathrm{mL}$ of $25(\mathrm{OH}) \mathrm{D}(\mathrm{p}<.001) .{ }^{43}$

\section{Vitamin D Toxicity}

Vitamin D toxicity is characterized by hypercalcemia and hypercalciuria, polyuria and seizures. ${ }^{54}$ The North American Institute of Medicine report classified levels higher than $125 \mathrm{nmol} / \mathrm{L}$ as toxic and represent potential harm. ${ }^{55}$ Holick et al defined as excess the levels above $100 \mathrm{ng} / \mathrm{mL}$ and intoxication for levels above $150 \mathrm{ng} / \mathrm{mL}{ }^{9}$ One of the most common causes of vitamin D toxicity is the excessive consumption of fortified products, ${ }^{56}$ which due to manufacturing errors have been supplemented in excess. A study conducted by Blank et al showed an increase in cases of hypervitaminosis in a population of the United States. 56 cases presented hypervitaminosis and 2 cases were fatal. ${ }^{57}$ The increasing use of vitamin $D$ treatments has also seen a substantial increase in the number of reports of vitamin D toxicity, due to inappropriate prescription and the use of high-dose over-the-counter preparations or unlicensed preparations. ${ }^{58}$ On the other hand, the VITAL study showed that supplementation with 2000 IU (50 $\mu \mathrm{g})$ does not generate adverse effects including hypercalcemia, kidney stones or kidney failure. ${ }^{59}$

Previously described studies conducted with megadoses and high doses have shown an increase in falls and fractures. ${ }^{15,43,45}$ This effect is likely to be a consequence of a central nervous toxicity, especially on cerebellar neurons, which contain a high density of vitamin D receptors. ${ }^{60}$

\section{Discussion}

For the purpose of this review, megadoses of vitamin D were defined as the administration of doses greater than 100,000 IU. In addition, fractional doses that exceed 100,000 IU of vitamin D should be considered as megadoses. $^{49,53}$

Although clinical trials evaluating the effect of vitamin D supplementation on the risk of falls are not uniform, it has been defined that deficient levels of vitamin $\mathrm{D}$ are associated with an increased risk of falls and fractures. ${ }^{61-63}$

In this review, several studies have shown that the use of supraphysiological doses of vitamin D does not denote greater clinical benefits in patients with insufficient serum levels, and which, in turn, could imply an increase in adverse effects, such as the increase in falls and fractures, ${ }^{15,43,45}$ greater loss of bone mass and increased markers of bone resorption, ${ }^{49}$ compared to those patients who receive adequate supplementation (8002000 IU), which report a positive effect in reducing the risk of falls and fractures.

The authors propose a vitamin D supplementation algorithm, based on the determination of serum levels of $25(\mathrm{OH}) \mathrm{D}$, risk factors and comorbidities as a prelude to start supplementing recommended doses according to international guidelines (Figure 2). ${ }^{9,55,64-66}$ It is important to highlight the individualization of the supplementation for each patient taking into account information such as age, sex, risk factors, history of falls and comorbidities.

\section{Conclusion}

Hypovitaminosis D is a widespread problem. The role of vitamin $\mathrm{D}$ in bone metabolism and its influence on the risk of falls and fractures is clear. It seems that doses of 800 to $2000 \mathrm{IU}$ daily are effective in maintaining serum levels above $30 \mathrm{ng} / \mathrm{mL}$. The ideal dose for vitamin D supplementation should be individualized according to the serum levels and risk factors of each patient. For years it has been discussed whether the use of high doses of vitamin $\mathrm{D}$, called megadoses, could be effective in maintaining adequate serum levels, reducing the risk of falls and hence fractures. The results of research studies make it clear that megadoses of vitamin D would have an opposite effect from what would be expected of them. The information presented shows that the Megadoses increase the risk of falls, fractures and toxicity, so this form of supplementation would not be the most appropriate. The daily dosage according to the needs of each patient seems to be safer and more effective.

\section{Author Contributions}

All authors made substantial contributions to conception and design, acquisition of data, or analysis and interpretation of data; took part in drafting the article or revising it critically for important intellectual content; gave final approval of the version to be published; and agree to be accountable for all aspects of the work. 


\section{Disclosure}

The authors report no conflicts of interest in this work.

\section{References}

1. Maldonado G, Guerrero R, Ríos C. Prevalencia de vitamina D en pacientes con enfermedades autoinmunes en Ecuador: estudio restrospectivo. Rev Colomb Reumatol. 2017;24(4):205-210. doi:10.1016/j.rcreu.2017.08.001

2. Holick M. Vitamin D deficiency. $N$ Engl J Med. 2007;357 (3):266-281. doi:10.1056/NEJMra070553

3. Wacker M, Holick M. Sunlight and Vitamin D. Dermatol-Endocrinol. 2013;5(1):51-108. doi:10.4161/derm.24494

4. Holick M, Chen T. Vitamin D deficiency: a world- wide problem with health consequences. Am J Clin Nutr. 2008;87(4):1080S-6S doi:10.1093/ajen/87.4.1080S

5. Moon RJ, Curtis EM, Davies JH, Cooper C, Harvey NC. Seasonal variation in Internet searches for vitamin D. Arch Osteoporos. 2017;12(1):10-13. doi:10.1007/s11657-017-0322-7

6. Hernigou P, Sitbon J, Dubory A, Auregan JC. Vitamin D history part III: the "modern times"- new questions for orthopaedic practice: deficiency, cell therapy, osteomalacia, fractures, supplementation, infections. Int Orthop. 2019;43(7):1755-1771. doi:10.1007/s00264019-04334-w

7. Bischoff-Ferrari HA, Willett WC, Orav EJ, et al. A pooled analysis of vitamin D dose requirements for fracture prevention. $N$ Engl J Med. 2012;367(1):40-49. doi:10.1056/NEJMoa1109617

8. Wahl DA, Cooper C, Ebeling PR, et al. A global representation of vitamin D status in healthy populations. Arch Osteoporos. 2012;7 (1-2):155-172. doi:10.1007/s11657-012-0093-0

9. Holick MF, Binkley NC, Bischoff-Ferrari HA, et al. Evaluation, treatment, and prevention of vitamin $\mathrm{D}$ deficiency: an endocrine society clinical practice guideline. $J$ Clin Endocrinol Metab. 2011;96(7):1911-1930. doi:10.1210/jc.2011-0385

10. Christakos S, Li S, De La Cruz J, Bikle DD. New developments in our understanding of vitamin D metabolism, action and treatment Metab Clin Exp. 2019;98:112-120. doi:10.1016/j.metabol.20 19.06.010

11. Heikinheimo RJ, Inkovaara JA, Harju EJ, et al. Annual injection of vitamin D and fractures of aged bones. Calcif Tissue Int. 1992;51 (2):105-110. doi:10.1007/BF00298497

12. Trivedi DP, Doll R, Khaw KT. Effect of four monthly oral vitamin D 3 (cholecalciferol) supplementation on fractures and mortality in men and women living in the community: randomised double blind controlled trial. BMJ. 2003;326(March):1-6.

13. Smith H, Anderson F, Raphael H, Maslin P, Crozier S, Cooper C. Effect of annual intramuscular vitamin D on fracture risk in elderly men and women-a population- based, randomized, double-blind, placebo-controlled trial. Rheumatology. 2007;46(12):1852-1857. doi:10.1093/rheumatology/kem240

14. Tarcin O, Yavuz DG, Ozben B, et al. Effect of vitamin D deficiency and replacement on endothelial function in asymptomatic subjects. J Clin Endocrinol Metab. 2009;94(10):4023-4030. doi:10.1210/ jc. 2008-1212

15. Sanders K, Stuart A, Williamson E, Simpson J, Kotowicz M, Young D. Annual high-dose oral vitamin D and falls and fractures in older women: a randomized controlled trial. JAMA. 2010;303 (18):1815-1822. doi:10.1001/jama.2010.594

16. Cashman KD, Dowling KG, Škrabáková Z, et al. Vitamin D deficiency in Europe: pandemic? Am J Clin Nutr. 2016;103 (4):1033-1044. doi:10.3945/ajcn.115.120873

17. van Schoor N, Lips P. Global overview of vitamin D status. Endocrinol Metab Clin North Am. 2017;46(4):845-870. doi:10.1016/j.ecl.2017.07.002
18. Schleicher RL, Sternberg MR, Lacher DA, et al. The vitamin D status of the US population from 1988 to 2010 using standardized serum concentrations of 25-hydroxyVitamin D shows recent modest increases. Am J Clin Nutr. 2016;104(2):454-461. doi:10.3945/ ajcn.115.127985

19. Young NP, Weinshenker BG, Parisi JE, et al. Perivenous demyelination: association with encephalomyelitis and comparison with pathologically confirmed multiple sclerosis. Brain. 2010;133(2):33-348. doi:10.1093/brain/awp321

20. Spiro A, Buttriss JL. Vitamin D: an overview of vitamin D status and intake in Europe. Nutr Bull. 2014;39(4):322-350. doi:10.1111/ nbu. 12108

21. Compston J, Cooper A, Cooper C, et al. UK clinical guideline for the prevention and treatment of osteoporosis. Arch Osteoporos. 2017;12 (1). doi:10.1007/s11657-017-0324-5.

22. Kanis J, McCloskey E, Johansson H, Cooper C, Rizzoli R, Reginster J. European guidance for the diagnosis and management of osteoporosis in postmenopausal women. Osteoporos Int. 2013;24 (1):23-57.

23. Lips P, Graafmans W, Ooms M, Bezemer P, Bouter L. Vitamin $\mathrm{D}$ supplementation and fracture incidence in elderly persons: a randomized, placebo- controlled clinical trial. Ann Intern Med. 1996;124(4):400-406. doi:10.7326/0003-4819-124-4-199602150-00003

24. Meyer H, Smedshaug G, Kvaavik E, Falch J, Tverdal A, Pedersen J. Can vitamin D supplementation reduce the risk of fracture in the elderly? A randomized controlled trial. J Bone Miner Res. 2002;17 (4):709-715. doi:10.1359/jbmr.2002.17.4.709

25. Gennari C. Calcium and vitamin D nutrition and bone disease of the elderly. Public Health Nutr. 2001;4(2b):547-559. doi:10.1079/ PHN2001140

26. Chapuy M, Arlot M, Duboeuf F. Vitamin D3 and calcium to prevent hip fractures in the elderly women. $N$ Engl J Med. 1992;327 (23):1637-1642. doi:10.1056/NEJM199212033272305

27. Dawson-Hughes B, Harris S, Krall E, Dallal G. Effect of calcium and vitamin $\mathrm{D}$ supplementation on bone density in men and women 65 years of age or older. $N$ Engl J Med. 1997;337(10):670-676. doi:10.1056/NEJM199709043371003

28. Yong WC, Sanguankeo A, Upala S. Effect of vitamin D supplementation in chronic widespread pain: a systematic review and meta-analysis. Clin Rheumatol. 2017;36(12):2825-2833. doi:10.1007/s10067-017-3754-y

29. Megadose vitamin supplementation and immunological function in the elderly. Nutr Rev. 1984;42(2):46-48. doi:10.1111/j.17534887.1984.tb02282.x

30. Cavalcante IG, de M, Silva AS, et al. Effect of vitamin D3 supplementation and influence of BsmI polymorphism of the VDR gene of the inflammatory profile and oxidative stress in elderly women with vitamin D insufficiency vitamin D3 megadose reduces inflammatory markers. Exp Gerontol. 2015;66:10-16. doi:10.1016/j.exger.2015.03.011

31. Pekkarinen T, Välimäki -V-V, Aarum $S$, et al. The same annual dose of 292000 IU of vitamin D3 (cholecalciferol) on either daily or four monthly basis for elderly women: 1-year comparative study of the effects on serum 25(OH)D3 concentrations and renal function. Clin Endocrinol (Oxf). 2010;72(4):455-461. doi:10.1111/j.13652265.2009.03637.x

32. Khaw K, Stewart A, Waayer D, Lawes C, Toop L, Camargo Jr C. Effect of monthly high-dose vitamin D supplementation on falls and non-vertebral fractures: secondary and post-hoc outcomes from the randomised, double-blind, placebo-controlled ViDA trial. Lancet Diabetes Endocrinol. 2017;5(6):438-447. doi:10.1016/S22138587(17)30103-1

33. Witham MD, Price RJG, Struthers AD, et al. Cholecalciferol treatment to reduce blood pressure in older patients with isolated systolic hypertension the VitDISH randomized controlled trial. JAMA Intern Med. 2013;173(18):1672-1679. doi:10.1001/jamainternmed.2013.9043 
34. Scragg R, Steward A, Waayer D. Effect of monthly high-dose vitamin D supplementation on cardiovascular disease in the vitamin D assessment study: a randomized clinical trial. JAMA Cardiol. 2017;6:608-616.

35. Trivedi D, Doll R, Khaw K. Effect of four monthly oral vitamin D3 (cholecalciferol) supplementation on fractures and mortality in men and women living in the community: randomised double blind controlled trial. $\mathrm{Br}$ Med J. 2003;326(7387):469. doi:10.1136/ bmj.326.7387.469

36. The National Heart Lung and Blood Institute PETAL Clinical Trials Network. Early high-dose vitamin D3 for critically ill, vitamin Ddeficient patients. N Engl J Med. 2019;381(26):2529-2540.

37. Jia H, Lubetkin EI, DeMichele K, Stark DS, Zack MM, Thompson WW. Prevalence, risk factors, and burden of disease for falls and balance or walking problems among older adults in the U.S. Prev Med (Baltim). 2019;126(April):105737. doi:10.1016/j. ypmed.2019.05.025

38. Murray C, Lopez A. Global and regional descriptive epidemiology of disability: incidence, prevalence, health expectations and years lived with disability. Global Burden Dis. 1996;1:201-246.

39. Tinetti M, Speechley M, Ginter S. Risk factors for falls among elderly persons living in the community. $N$ Engl $J$ Med. 1988;319:1701-1707.

40. Blake A, Morgan K, Bendall M, et al. Falls by elderly people at home: prevalence and associated factors. Age Ageing. 1988;17 (6):365-372. doi:10.1093/ageing/17.6.365

41. Tromp A, Pluijm S, Smitt J. Fall-risk screening test: a prospective study on predictors for falls in community-dwelling elderly. $J$ Clin Epidemiol. 2001;54(8):837-844. doi:10.1016/S0895-4356(01)00349-3

42. Ceglia L. Vitamin D and skeletal muscle tissue and function. Mol Aspects Med. 2008;29(6):407-414. doi:10.1016/j.mam.2008.07.002

43. Bischoff-Ferrari HA, Dawson-Hughes B, John Orav E, et al. Monthly high-dose Vitamin D treatment for the prevention of functional decline a randomized clinical trial. JAMA Intern Med. 2016;176 (2):175-183. doi:10.1001/jamainternmed.2015.7148

44. Snijder MB, Van Schoor NM, Pluijm SMF, Van Dam RM, Visser M, Lips P. Vitamin D status in relation to one-year risk of recurrent falling in older men and women. J Clin Endocrinol Metab. 2006;91 (8):2980-2985. doi:10.1210/jc.2006-0510

45. Smith LM, Gallagher JC, Suiter C. Medium doses of daily vitamin D decrease falls and higher doses of daily vitamin D3 increase falls: a randomized clinical trial. $J$ Steroid Biochem Mol Biol. 2017;173:317-322. doi:10.1016/j.jsbmb.2017.03.015

46. Latham NK, Anderson CS, Lee A, Bennett DA, Moseley A, Cameron ID. A randomized, controlled trial of quadriceps resistance exercise and vitamin D in frail older people: the frailty interventions trial in elderly subjects (FITNESS). $J$ Am Geriatr Soc. 2003;51 (3):291-299. doi:10.1046/j.1532-5415.2003.51101.x

47. Lyons RA, Johansen A, Brophy S, et al. Preventing fractures among older people living in institutional care: a pragmatic randomised double blind placebo controlled trial of vitamin D supplementation. Osteoporos Int. 2007;18(6):811-818. doi:10.1007/s00198-006-0309-5

48. Reid I, Horne A, Mihov B. Effect of monthly high-dose vitamin D on bone density in community-dwelling older adults substudy of randomized controlled trial. $J$ Intern Med. 2017;282(5):452-460. doi:10.1111/joim.12651

49. Burt LA, Billington EO, Rose MS, Raymond DA, Hanley DA, Boyd SK. Effect of high-dose vitamin D supplementation on volumetric bone density and bone strength. JAMA. 2019;322(8):736.

50. Carbonare LD, Valenti MT, Del Forno F, Piacentini G, Pietrobelli A. Vitamin D daily versus monthly administration: bone turnover and adipose tissue influences. Nutrients. 2018;10(12):1-9.
51. Holmøy T, Lindstrøm JC, Eriksen EF, Steffensen LH, Kampman MT. High dose vitamin D supplementation does not affect biochemical bone markers in multiple sclerosis - a randomized controlled trial. BMC Neurol. 2017;17(1):1-6. doi:10.1186/s12883-017-0851-0

52. Ish-shalom S, Segal E, Salganik T, Raz B, Bromberg IL, Vieth R. Comparison of daily, weekly, and monthly vitamin elderly hip fracture patients. $J$ Clin Endocrinol Metabol. 2008;93 (September):3430-3435.

53. Singh V, Misra AK, Singh M, et al. An open - label, randomized, 10 weeks prospective study on the efficacy of vitamin D (daily low dose and weekly high dose) in vitamin D deficient patients. J Family Med Prim Care. 2019;8(6):1958.

54. Pilz S, März W, Cashman KD, et al. Rationale and plan for vitamin $\mathrm{D}$ food fortification: a review and guidance paper. Front Endocrinol (Lausanne). 2018;9(JUL):1-16. doi:10.3389/fendo.2018.00373

55. Ross AC, Manson JAE, Abrams SA, et al. The 2011 report on dietary reference intakes for calcium and vitamin D from the Institute of Medicine: what clinicians need to know. J Clin Endocrinol Metab. 2011;96(1):53-58. doi:10.1210/jc.2010-2704

56. Taylor PN, Davies JS. A review of the growing risk of vitamin D toxicity from inappropriate practice. $\mathrm{Br} J$ Clin Pharmacol. 2018;84(6):1121-1127. doi:10.1111/bcp.13573

57. Blank S, Scanlon KS, Sinks TH, Lett S, Falk H. An outbreak of hypervitaminosis D associated with the overfortification of milk from a home-delivery dairy. Am J Public Health. 1995;85(5):656-659. doi:10.2105/AJPH.85.5.656

58. Sempos C, Heijboer A, Biklee D, Billerslev J, Bouillon R, Brannon P. Vitamin D assays and the definition of hypovitaminosis D: results from the First International Conference on Controversies in Vitamin D. Br J Clin Pharmacol. 2018;84(10):2194-2207. doi:10.1111/ bcp. 13652

59. Manson JAE, Cook NR, Lee IM, et al. Vitamin D supplements and prevention of cancer and cardiovascular disease. $N$ Engl $J$ Med. 2019;380(1):33-44. doi:10.1056/NEJMoa1809944

60. Harms LR, Burne THJ, Eyles DW, McGrath JJ. Vitamin D and the brain. Best Pract Res Clin Endocrinol Metab. 2011;25(4):657-669. doi:10.1016/j.beem.2011.05.009

61. Murad MH, Elamin KB, Abu Elnour NO, et al. The effect of vitamin D on falls: a systematic review and meta-analysis. J Clin Endocrinol Metab. 2011;96(10):2997-3006. doi:10.1210/jc.2011-1193

62. Bolland MJ, Grey A, Gamble GD, Reid IR. Vitamin D supplementation and falls: a trial sequential meta-analysis. Lancet Diabetes Endocrinol. 2014;2(7):573-580. doi:10.1016/S22138587(14)70068-3

63. Bolland MJ, Grey A, Reid IR. Differences in overlapping meta-analyses of vitamin D supplements and falls. $J$ Clin Endocrinol Metab. 2014;99(11):4265-4272. doi:10.1210/jc.20142562

64. German Nutrition Society (DGE). New reference values for vitamin D. Ann Nutr Metab. 2012;60(4):241-246. doi:10.1159/000337547

65. Pludowski P, Karczmarewicz E, Bayer M, Carter G, Chelbna-Sokol D, Czech-Kowalska J. Practical guidelines for the supplementation of vitamin D and the treatment of deficits in Central Europe - recommended vitamin D intakes in the general population and groups at risk of vitamin D deficiency. Endokrynol Pol. 2013;64(4):319-327. doi:10.5603/EP.2013.0012

66. Haq A, Wimalawansa S, Pludowski P, Al Anouti F. Clinical practice guidelines for vitamin D in the United Arab Emirates. J Steroid Biochem Mol. 2018;175:4-11. doi:10.1016/j.jsbmb.2016.09.021 


\section{Publish your work in this journal}

Open Access Rheumatology Research and Reviews is an international, peer-reviewed, open access journal publishing original research, reports, editorials, reviews and commentaries on all aspects of clinical and experimental rheumatology in the clinic and laboratory including the following topics: Pathology, pathophysiology of rheumatological diseases; Investigation, treatment and managemen of rheumatological diseases; Clinical trials and novel pharmacological approaches for the treatment of rheumatological disorders. The manuscript management system is completely online and includes a very quick and fair peer-review system, which is all easy to use. Visit http://www.dovepress.com/testimonials.php to read real quotes from published authors. 